\title{
Pathology of cultured paua Haliotis iris infected with a novel haplosporidian parasite, with some observations on the course of disease
}

\author{
B. K. Diggles ${ }^{1, *}$, J. Nichol ${ }^{2}$, P. M. Hine ${ }^{1, * *}$, S. Wakefield ${ }^{2}$, N. Cochennec-Laureau ${ }^{3}$, \\ R. D. Roberts ${ }^{4}$, C. S. Friedman ${ }^{5}$ \\ ${ }^{1}$ National Institute of Water and Atmospheric Research, PO Box 14-901, Kilbirnie, Wellington, New Zealand \\ ${ }^{2}$ School of Medicine, University of Otago, Private Bag 7902, Wellington South, New Zealand \\ ${ }^{3}$ Laboratoire de Genetique et Pathologie, IFREMER, BP 133, 17390, La Tremblade, France \\ ${ }^{4}$ Cawthron Institute, Private Bag 2, Nelson, New Zealand \\ ${ }^{5}$ School of Aquatic and Fishery Science, University of Washington, PO Box 355020, Seattle, Washington 98195, USA
}

\begin{abstract}
Mortalities among juvenile paua Haliotis iris Martyn 1784 in a commercial culture facility were reported in April 2000. Histology of moribund paua showed heavy systemic infections of a uni- to multi-nucleate stage of a novel organism later confirmed by transmission electron microscopy (TEM) and molecular studies to be a haplosporidian. Multinucleate plasmodia up to $25 \mu \mathrm{m}$ diameter with up to 17 nuclei were detectable in wet preparations of hemolymph from heavily infected paua. The presence of the haplosporidian in the affected facility was associated with mortalities of slow growing 'runt' paua during the summer months. Total mortalities in affected raceways 6 mo after mortalities began were between 82.5 and $90 \%$. Heavily infected paua exhibited behavioural abnormalities including lethargy, loss of righting reflex, and were easily detached from surfaces. Some heavily infected paua exhibited oedema and pale lesions in the foot and mantle, but no reliable gross signs of disease were noted. Light infections of the haplosporidian were also found in apparently healthy paua from the facility. Histology indicated that the early stages of infection were characterised by small numbers of plasmodia in the connective tissue surrounding the gut, amongst glial cells adjacent to nerves in the mantle and foot and within gill lamellae. In heavy infections, large numbers of small plasmodia (mean size $5.5 \times 7 \mu \mathrm{m}$ in histological sections) were present in the hemolymph, gills, heart, kidneys, mantle, foot, epipodium and connective tissue of the digestive gland. Infections were not transferred horizontally at 14 and $19^{\circ} \mathrm{C}$ after cohabiting heavily infected paua with uninfected paua for 3 mo in aquaria, or 3 mo after injecting healthy paua with hemolymph containing haplosporidian plasmodia. This may indicate that the prepatent period for disease is longer than $3 \mathrm{mo}$, that disease is not expressed below $20^{\circ} \mathrm{C}$, or that an intermediate host is required for transmission. Spore formation was not observed in juvenile paua but sporocyst-like bodies containing putative spores were observed amongst haplosporidian plasmodia in the right kidney of poorly performing adult paua collected from the wild.
\end{abstract}

KEY WORDS: Haplosporidia $\cdot$ Abalone $\cdot$ Aquaculture $\cdot$ Pathology $\cdot$ Disease $\cdot$ New Zealand Resale or republication not permitted without written consent of the publisher

\section{INTRODUCTION}

*E-mail: b.diggles@niwa.cri.nz

${ }^{* *}$ Present address: National Centre for Disease Investigation, MAF Operations, PO Box 40742, Upper Hutt, New Zealand
In New Zealand, abalone Haliotis sp. (locally known as paua) are high value shellfish which form the basis of important commercial and recreational fisheries. 
The commercial fishery is based almost entirely on the black-footed paua $H$. iris while recreational fishers take mostly $H$. iris but also small numbers of the yellow-footed paua $H$. australis (see Annala et al. 2000). The commercial fishery is limited by a total allowable catch (TAC) of around $1400 \mathrm{t} \mathrm{yr}^{-1}$ and is near full exploitation (Annala et al. 2000), which has lead to increased interest in the culture of paua. Little is known about diseases of $H$. iris in New Zealand. The only disease of paua formally described to date has been brown-coloured lesions on the inside of the shell, presumed to be of fungal aetiology (Grindley et al. 1998). Severe cases of this disease may result in shell loss. However, mortality rates of 50 to $66 \%$, reportedly without shell loss, have been recorded in hatcheryreared paua used in experiments designed to determine optimal culturing methods (Clarke \& Creese 1998, Preece \& Mladenov 1999). These high rates of mortality are usually considered to be due to suboptimal rearing conditions, and thorough investigations of the affected paua for disease are seldom undertaken. In other parts of the world a number of diseases are known to cause mortality in cultured and wild abalone. These include amyotrophia of Japanese black abalone Nordotis discus discus with atrophy of the foot, presumably due to an uncharacterised virus (Nakatsugawa et al. 1999), and withering disease of abalone Haliotis sp. on the West coast of the United States caused by 'Candidatus Xenohaliotis californiensis', a rickettsial organism (Gardner et al. 1995, Friedman et al. 2000).

In April 2000, a commercial paua farm experienced mortality rates of Haliotis iris that were well above normal. Affected paua showed only weak adherence to the glass-fibre raceways, an oedematous foot with pale areas in the foot and mantle, and inability to right themselves when turned over. Histological, molecular and electron microscopic studies determined that the mortalities were associated with infection by a novel parasite belonging to the haplosporidia (Hine et al. 2002, Reece \& Stokes in press). This paper describes the pathology and some aspects of the course of disease in $H$. iris infected with this haplosporidian.

\section{MATERIALS AND METHODS}

Culture farm surveys. In an initial health examination during April 2000, paua Haliotis iris from 2 different seed sources were collected from the affected facility for microscopic examination. Ten affected paua (mean shell length $=28.7 \mathrm{~mm}$, range $=23.3-34.6 \mathrm{~mm}$ ) and 5 apparently healthy paua (mean length = $27.1 \mathrm{~mm}$, range $=22.2-30.8 \mathrm{~mm}$ ) from one seed source were collected from Raceway $\mathrm{G}$. The paua in Raceway
$G$ had resided there for approximately 10 mo after being stocked in June 1999. Five apparently healthy paua (mean length $=16.2 \mathrm{~mm}$, range $=15.2-18.3 \mathrm{~mm}$ ) from a separate seed source were collected from Raceway A. These paua had resided in Raceway A for approximately 10 mo after being stocked in June 1999. Paua were excised from the shell, killed by severing the cerebral and pedal ganglia, preserved in Davidson's fixative for $24 \mathrm{~h}$, then transferred to $70 \%$ ethanol and processed for paraffin histology (Luna 1968). Deparaffinised, $5 \mu \mathrm{m}$ sections were stained with hematoxylin and eosin ( $\mathrm{H} \& \mathrm{E}$ ) and examined using bright field microscopy.

In August and September 2000, additional paua ( $\mathrm{n}=$ 131 , mean length $=27.8 \mathrm{~mm}$, range $=15-52.5 \mathrm{~mm}$ ) were collected from 3 raceways (A, E and $G$ ) at the affected facility for further histological analysis. Paua from 2 affected raceways (A and G) were obtained by collecting weakly adhering paua detached from the raceways with a stream of seawater from a medium pressure hose. Apparently healthy paua from Raceway E were obtained by removing individuals by hand. The paua in raceway $E$ had resided in that raceway for 6 to 7 mo after being stocked in February 2000. Each paua was measured to the nearest $0.5 \mathrm{~mm}$, and examined for gross signs of disease. Wet smears were made from hemolymph obtained from the pallial sinus of selected paua using a 25 gauge hypodermic needle and sterile $1 \mathrm{ml}$ syringe. Each paua was then excised from the shell, killed by severing the cerebral and pedal ganglia with a scalpel, and fixed in $10 \%(\mathrm{v} / \mathrm{v})$ formalin in $0.22 \mu \mathrm{m}$ filtered seawater or Davidson's fixative for at least $48 \mathrm{~h}$ before being processed for paraffin histology and stained as described above. Additional samples of formalin fixed paua $(n=65)$ were obtained from 3 spat suppliers ( 2 of which had supplied juvenile paua to the affected farm). These were screened for the haplosporidian by histology using the methods described above.

Laboratory studies. Around 180 live paua from the affected facility were transported to Wellington, New Zealand, in September 2000 and maintained at the National Institute of Water and Atmospheric Research (NIWA) Greta Point campus in quarantine facilities which comprised 201 static aquaria supplied with aeration and activated charcoal airlift filters. Three aquaria were maintained at $19 \pm 1^{\circ} \mathrm{C}$ (Aquaria 1, 2 and 3 ), and three at $14 \pm 2^{\circ} \mathrm{C}$ (Aquaria 5, 6 and 7), and 30 paua were placed in each aquarium. Low numbers of potential intermediate hosts collected from the affected facility (including mudworms Polydora sp. and ship worms [Family Teredinidae]) were also placed in Aquaria 3 and 7. One week later 320 uninfected paua (mean length $=19.7 \mathrm{~mm}$, range = 14-27 mm) were obtained from a spat supplier and 60 
of these were found to be uninfected by the haplosporidian using histology as described above. Of the remaining 260 presumably uninfected paua, 30 were placed in each of the 6 aquaria containing infected paua for cohabitation experiments. Subsamples of 15 of the uninfected paua in Aquaria 2 and 3 at $19^{\circ} \mathrm{C}$ and Aquaria 6 and 7 at $14^{\circ} \mathrm{C}$ were injected with 0.05 to $0.1 \mathrm{ml}$ of hemolymph from infected paua via the pallial sinus. The remaining 80 uninfected paua were placed in 2 aquaria, 40 into Aquarium 4 at $19^{\circ} \mathrm{C}$ and 40 into Aquarium 8 at $14^{\circ} \mathrm{C}$, and used as controls (Table 1). The uninfected paua were identified by their smaller size and a lack of the biofouling organisms on the shell (such as the tube worm Neodexiospira sp. juvenile mud worm Polydora sp. and the bryozoan-like organism Magnifolliculina sp.), which were used as natural tags to identify paua from the affected facility. Uninfected paua injected with hemolymph were tagged on the shell with an indelible waterproof marker. Paua in all aquaria were fed dried Gracilaria (Rhodophyta) every second day and a 1/2 water exchange was performed twice weekly to maintain acceptable water quality. Any infected and uninfected paua that died during the experiment were examined by histology for the presence of the haplosporidian. Three months after introduction of the uninfected paua, the experiment was terminated and all surviving paua were measured to the nearest $0.5 \mathrm{~mm}$, killed as described above, and fixed in $10 \%(\mathrm{v} / \mathrm{v})$ formalin in $0.22 \mu \mathrm{m}$ filtered seawater. Subsamples of the previously uninfected paua from each aquarium were processed and examined by histology for the presence of the haplosporidian as described previously. A total of 172 previously uninfected paua were examined to provide $95 \%$ confidence of detecting $\geq 2 \%$ disease incidence, assuming histology detected all haplosporidian infections. Sections were routinely stained with $H \& E$, while sections from specimens of special interest were also stained with the Ziehl-Neilsen method for acid-fast organisms. Selected wax blocks containing specimens of special interest were deparaffinised, and prepared for transmission electron microscopy (TEM) as follows. Tissues of interest were rehydrated, washed in sodium cacodylate buffer and fixed in $1 \%$ osmium tetraoxide for $1 \mathrm{~h}$, rewashed in sodium cacodylate buffer, then dehydrated in ascending ethanol series, infiltrated with Spurr's resin and ultrathin sections were cut and stained with uranyl acetate and lead citrate before being examined on a JEOL 6100 TEM.

In situ hybridisation. A small number of diseased paua obtained from the affected facility in September 2000 were fixed in either $70 \%$ ethanol $(n=2)$ or Davidson's fixative ( $\mathrm{n}=2$ ) for no more than $48 \mathrm{~h}$ before being transferred to 100 and $70 \%$ ethanol, respectively. Samples were stored at $4^{\circ} \mathrm{C}$ for 6 mo before they were embedded in wax and $6 \mu \mathrm{m}$ sections were cut and placed on aminoalkylsilane coated slides (Silane-prep slides, Sigma). After baking in an oven overnight at $50^{\circ} \mathrm{C}$ the sections were prepared for in situ hybridisation (ISH) as follows. The sections were dewaxed in 2 washes of xylene for $10 \mathrm{~min}$ followed by 2 washes in absolute ethanol for $10 \mathrm{~min}$, then rehydrated in a descending ethanol series. The sections were then treated with Proteinase $\mathrm{K}\left(100 \mu \mathrm{g} \mathrm{ml} \mathrm{m}^{-1}\right)$ in TE Buffer

Table 1. Haliotis iris. Details of experimental design and results of laboratory experiments exposing apparently healthy paua to paua infected with the haplosporidian parasite. C: cohabitation, I: injection, IH: intermediate hosts, -: not applicable

\begin{tabular}{|c|c|c|c|c|c|c|c|c|c|}
\hline & 1 & 2 & 3 & 4 & 5 & 6 & 7 & 8 & All \\
\hline Treatment & $\mathrm{C}$ & C, I & $\mathrm{C}, \mathrm{I}, \mathrm{IH}$ & Control & $\mathrm{C}$ & $\mathrm{C}, \mathrm{I}$ & $\mathrm{C}, \mathrm{I}, \mathrm{IH}$ & Control & - \\
\hline Water temperature $\left({ }^{\circ} \mathrm{C}\right)$ & 19 & 19 & 19 & 19 & 14 & 14 & 14 & 14 & - \\
\hline $\begin{array}{l}\text { No. of apparently } \\
\text { healthy paua }\end{array}$ & 30 & 30 & 30 & 40 & 30 & 30 & 30 & 40 & 260 \\
\hline No. infected paua & 30 & 30 & 30 & 0 & 30 & 30 & 30 & 0 & 180 \\
\hline $\begin{array}{l}\text { No. apparently infected paua } \\
\text { injected with infected } \\
\text { hemolymph }\end{array}$ & 0 & 15 & 15 & 0 & 0 & 15 & 15 & 0 & 60 \\
\hline $\begin{array}{l}\% \text { mortality of apparently } \\
\text { healthy paua after } 90 \mathrm{~d} \\
\% \text { mortality of infected }\end{array}$ & 100 & 100 & 100 & 100 & 60 & 50 & 50 & 31 & 60.7 \\
\hline $\begin{array}{l}\text { paua after } 97 \mathrm{~d} \\
\text { No. apparently healthy } \\
\text { paua examined for }\end{array}$ & 100 & 100 & 100 & - & 73 & 73 & 83 & - & 88.3 \\
\hline $\begin{array}{l}\text { haplosporidian } \\
\% \text { apparently healthy } \\
\text { paua positive for }\end{array}$ & 15 & 15 & 21 & 15 & 23 & 30 & 23 & 30 & 172 \\
\hline haplosporidian & 0 & 0 & 0 & 0 & 0 & 0 & 0 & 0 & 0 \\
\hline
\end{tabular}


(50 mM Tris, $10 \mathrm{mM} \mathrm{EDTA)} \mathrm{at} 37^{\circ} \mathrm{C}$ for $25 \mathrm{~min}$, dehydrated by immersion in ethanol series and air dried. Hybridisation was carried out using $50 \mu \mathrm{l}$ of a hybridisation buffer $(4 \times \mathrm{SSC}, 50 \%$ formamide, $1 \times$ Denhardt's solution, $250 \mu \mathrm{g} \mathrm{ml}^{-1}$ yeast tRNA, $10 \%$ dextran sulfate) containing approximately $10 \mathrm{ng}$ of a digoxigeninlabeled probe (DIG-11-dUTP, Boehringer Mannheim) using the primers BO $\left(5^{\prime}\right.$ CAT TTA ATT GGT CGG GCC GC $\left.3^{\prime}\right)$ and BOAS (5' TCT GAT CGT CTT CGA TCC CC $3^{\prime}$ ) designed by Cochennec et al. (2000) for detecting Bonamia ostreae. The PCR protocols used to label the probe are detailed in Cochennec et al. (2000). Sections were covered with plastic coverslips and incubated at $95^{\circ} \mathrm{C}$ for $3 \mathrm{~min}$ on a heating block before being cooled on ice for $1 \mathrm{~min}$ and placed in a humid chamber overnight at $42^{\circ} \mathrm{C}$. Sections were then washed twice for $5 \mathrm{~min}$ in $2 \times \mathrm{SSC}$ at room temperature and once for $10 \mathrm{~min}$ in $0.4 \times \mathrm{SSC}$ at $42^{\circ} \mathrm{C}$. Detection steps were performed by enzyme immunoassay and an enzymecatalyzed colour reaction using the manufacturer's instructions (DIG nucleic acid detection kit, Boehringer Mannheim).

Screening of broodstock paua. A group of approximately 60 adult paua were collected from Whangarei and Coromandel in northern New Zealand in mid to late 2000 and maintained for over 6 months at the NIWA Mahanga Bay Aquaculture Research Facility as broodstock as part of a spat production programme. A subsample of poorly performing $(\mathrm{n}=16$, mean shell length $=112.25 \mathrm{~mm}$, range $=101-125 \mathrm{~mm}$ ) paua, which due to their poor condition were not used to produce spat, was examined using histology in April and May 2001. These paua were killed as described above and 5 samples from each paua, containing foot, mantle, epipodium, gill, kidneys, and digestive gland tissues, were excised and fixed in $10 \%$ formalin in filtered seawater before being processed and examined by histology for the presence of the haplosporidian as described previously. Sections were routinely stained with H\&E, while sections from specimens of special interest were also stained with the Ziehl-Neilsen method for acidfast organisms.

\section{RESULTS}

\section{Onset of disease}

The outbreak of the disease at the affected facility was first recognised after an increase in mortalities in Raceways G and A in early April 2000, approximately 10 mo after receiving the stock (Fig. 1), following a drop in water temperature to $18^{\circ} \mathrm{C}$. Relatively high water temperatures $\left(22^{\circ} \mathrm{C}\right)$ were noted during the month prior to the increased mortalities.
Mortalities in Raceways $\mathrm{G}$ and $\mathrm{A}$ jumped from an average of $0.24 \% \mathrm{wk}^{-1}$ over the previous $40 \mathrm{wk}$, to $3.4 \%$ for the week ending April 8, 2000. Affected paua exhibited behavioural abnormalities including lethargy, loss of righting reflex, and were easily detached from surfaces. Biofouling organisms such as the tube worm Neodexiospira sp., juvenile mud worm Polydora sp. and the bryozoan-like organism Magnifolliculina sp. were apparent on the shells of all paua from the affected facility. The peak of mortality in affected raceways during April 2000 coincided with 2 separate attempts at treatment using freshwater (30 s) and chlorine (10 ppm for $10 \mathrm{~s}$ ) dip treatments. Mortalities in the $4 \mathrm{wk}$ following the treatments peaked at $24 \% \mathrm{wk}^{-1}$ (Fig. 1), before declining to 1 to $7 \% \mathrm{wk}^{-1}$ for the remainder of the winter months until the paua were culled in September 2000. Total mortality in Raceways A and G 6 mo after mortalities began (16 mo after stocking) was $82.5 \%$ (Fig. 1). Apparently healthy paua in Raceway E were exposed to the same treatments as the affected stock. The mortality of these apparently healthy paua increased to 3 to $6 \% \mathrm{wk}^{-1}$ in the $2 \mathrm{wk}$ following treatment, then returned to background levels until mortalities increased during the summer of 2000/2001 and a cumulative mortality of over $90 \%$ was recorded for Raceway E by April 2001 (Fig. 1).

\section{Culture farm surveys}

April 2000. Microscopic examination of stained tissue sections of the ten affected paua from raceway $G$ revealed that every individual had a systemic infection with uni- to multi-nucleated, haplosporidian-like plasmodia. Relatively few or no host hemocytes were visible in heavily infected paua compared to uninfected, apparently healthy paua. The plasmodia averaged $5.48 \pm 1.33 \times 6.92 \pm 2.56 \mu \mathrm{m}$ in diameter in tissue sections with a range of $3.49-8.88 \times 3.49-16.69 \mu \mathrm{m}$ $(\mathrm{n}=45)$. Larger plasmodia were observed in lighter infections and in tissues that typically hosted fewer organisms such as the foot muscle. Up to 9 nuclei, each with marginated chromatin, were observed within cross sections of single plasmodia. Spherical nuclei averaged approximately $2.34 \mu \mathrm{m}$ in diameter with a mean number of $2.177 \pm 1.18(\mathrm{n}=226)$ nuclei observed in a single plasmodium. Two of the five apparently healthy paua from Raceway G had systemic haplosporidian infections. Two paua were patently uninfected and a single plasmodium was observed between gill lamellae in the remaining animal. Two multinucleated plasmodia were observed within the hemolymph spaces of the gills of one of the 5 paua from Raceway A. 


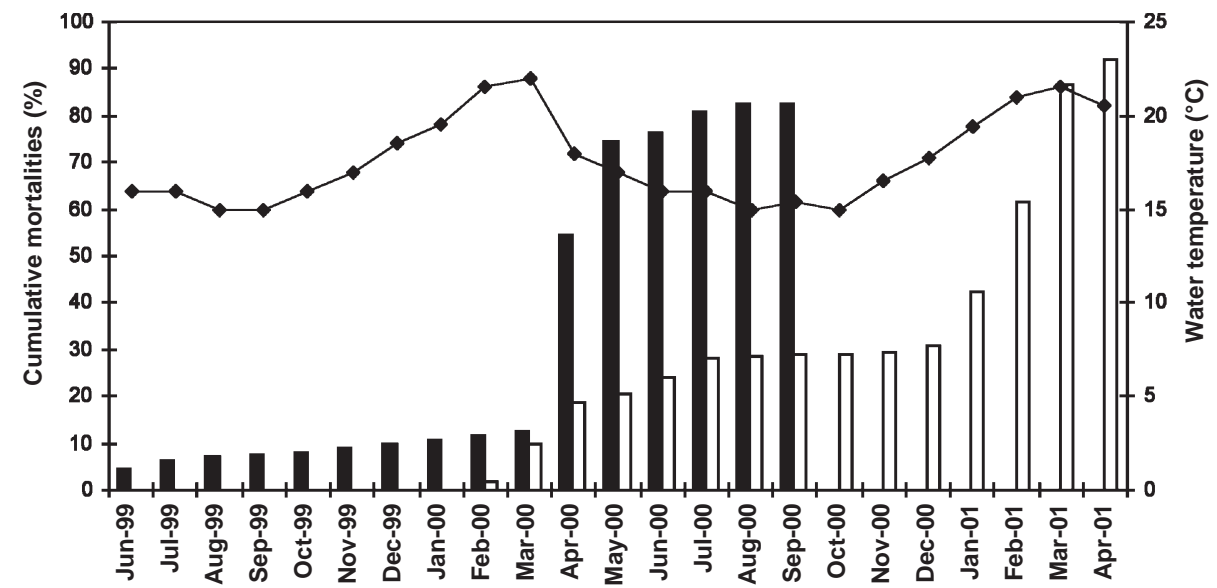

Fig. 1. Haliotis iris. Mortalities of paua (as a percentage of stock) associated with infection with the haplosporidian parasite. Heavy mortalities in April and May 2000 in affected Raceways A and G (solid bars) were exacerbated by brief freshwater (30 s) and chlorine (10 ppm for $10 \mathrm{~s}$ ) dip treatments, as indicated by increased mortality in apparently healthy paua (open bars) subjected to similar treatments in an adjacent raceway (E). Mortalities in Raceway E increased over the summer of 2000/2001 as water temperatures approached $20^{\circ} \mathrm{C}$. $-\longrightarrow-=$ water temperature
August and September 2000. Haplosporidian plasmodia were observed using histology in $50 \%$ of paua from Raceway $A, 87 \%$ of paua in raceway $G$, and $0 \%$ of paua in Raceway E. The occurrence of the haplosporidian in the affected raceways $A$ and $G$ was associated with the presence of slow growing 'runt' paua in these raceways. Infections ranged from low numbers of haplosporidians in apparently healthy paua to massive systemic infections in moribund paua.

Multinucleate plasmodia up to $25 \mu \mathrm{m}$ diameter with up to 17 nuclei were detectable in wet preparations of hemolymph from heavily infected paua (Figs. $2 \& 3$ ), but not from apparently healthy paua which were later shown by histology to carry light infections of the haplosporidian. Some, but not all, heavily infected paua exhibited oedema and pale lesions in the foot and mantle; however, besides the behavioural abnormalities, no reliable gross signs of disease were noted. Other pathologies noted at low to moderate prevalences included bacterial infections of the mantle and foot, foci of non-specific necrosis in various organs, infestations of ectocommensal ciliates on the mantle and gills, and the presence of oocysts of a gregarine (probably Nematopsis sp.) in the gills of $2 \%$ of paua from Raceway G (Table 2).

Surveys of paua $(n=65)$ obtained from 3 other spat suppliers found no evidence of infection with the haplosporidian. The pathological findings from the paua from other facilities showed evidence of bacterial infection (15\% prevalence in one facility, $20 \%$ in two others), infestations of the gill and mantle by ectocommensal ciliates (15\% prevalence in one facility), foci of non-specific necrosis ( $5 \%$ prevalence in one facility, $25 \%$ in another), and infection by a rickettsiae-like organism in the gut epithelium ( $15 \%$ prevalence in one facility, $5 \%$ prevalence in another) (Table 2). On the basis of the apparently restricted distribution of the haplosporidian, paua held in Raceways A and G in the affected facility were subsequently destroyed and the raceways were decon- taminated with chlorine in September 2000. Mortality rates in the paua remaining in Raceway E remained low during the cooler months but increased during the summer of 2000/2001 (Fig. 1). Histology of 5 moribund paua in April 2001 found that these mortalities were again associated with the presence of heavy infections with the haplosporidian parasite.

Histology of affected paua showed that each individual plasmodium was surrounded by a clear area which made detection of plasmodia relatively easy, due to the halo-like appearance of surrounding host tissue (Fig. 4). Light infections were characterised by low numbers of haplosporidian plasmodia mainly amongst glial cells around the periphery of nerves of the mantle and foot (Fig. 5), and in the connective tissues surrounding the gastrointestinal tract. Heavy infections were characterised by large numbers of plasmodia within the epithelium of the gut (Fig. 6) and intestine, with increasing numbers of plasmodia in the hemolymph spaces of the foot, mantle (Fig. 7), epipodium (Fig. 8), gills (Fig. 9), heart and left kidney (Fig. 10). Plasmodia were also present in the connective tissues of the right kidney (Fig. 11) and digestive gland (Fig. 12), but rarely inside the epithelium of these organs. The occurrence of the plasmodia in the foot, mantle, epipodium and connective tissue surrounding the gut was sometimes associated with hemocytosis in light infections (Fig. 13). Host responses were rare in heavily infected paua. No spore stages were observed in material obtained from juvenile paua from the affected facility.

\section{Laboratory studies}

Examination of apparently healthy paua by histology found that cohabitation with infected paua for 3 mo did not result in detectable transfer of haplosporidian infections from infected to uninfected paua. Similarly, no haplosporidian infections were observed in uninfected 


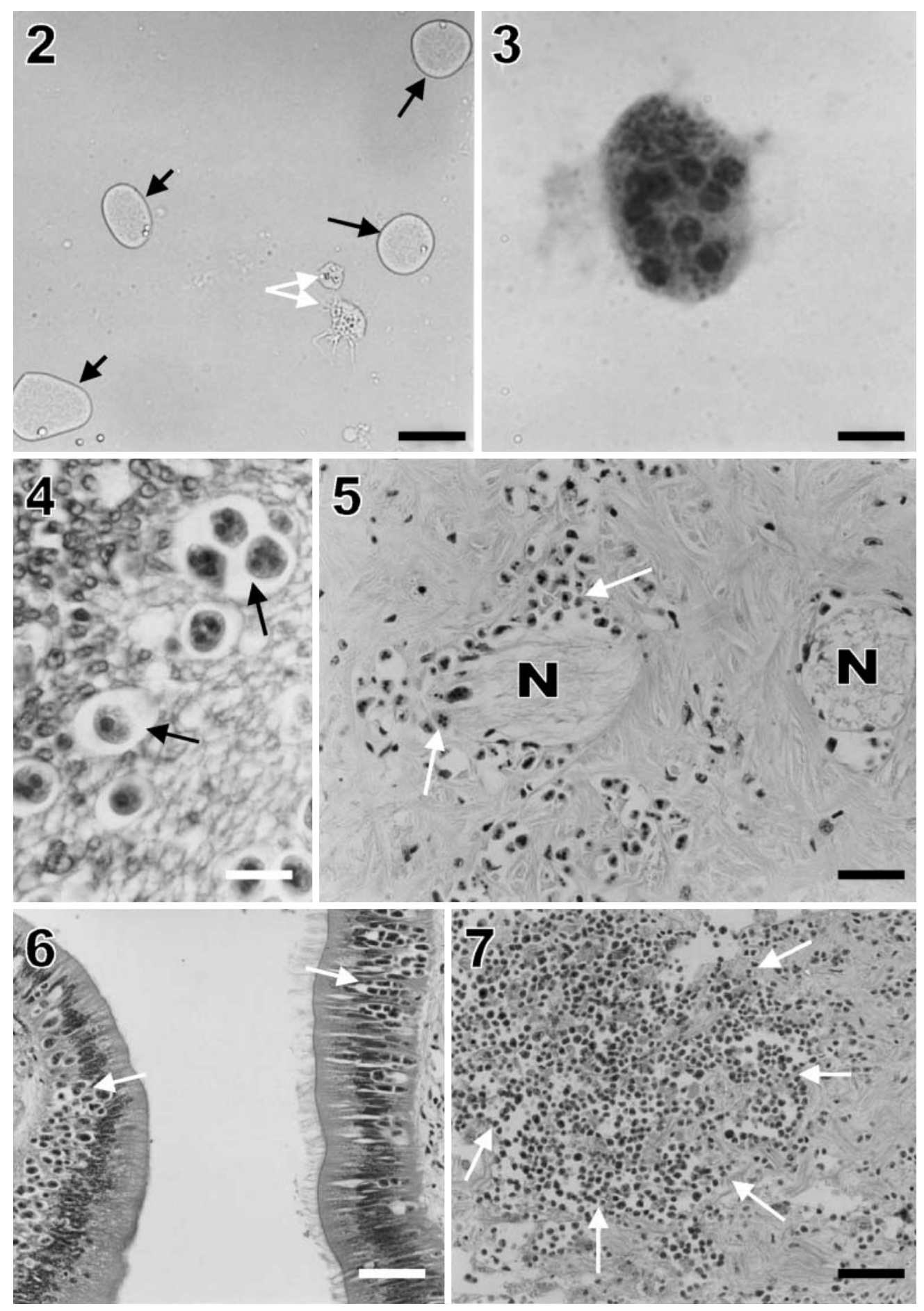

Figs. 2 to 7. Haliotis iris infected with a haplosporidian parasite. Fig. 2. Wet preparation of hemolymph from a heavily infected juvenile paua. Note 4 large, ovoid-shaped multinucleate haplosporidian plasmodia (black arrows), compared to the relatively small, irregularly shaped hemocytes (white arrows). Scale bar $=22 \mu \mathrm{m}$. Fig. 3. A plasmodium from an air-dried hemolymph smear stained with giemsa to demonstrate the multiple nuclei — this specimen having 9 nuclei. Scale bar $=5.5 \mu \mathrm{m}$. Fig. 4 . Uni- and multi-nucleate haplosporidian plasmodia (arrows) inside tissue of the gut epithelium, showing the distinctive clear space, or halo, surrounding each parasite. Scale bar $=11 \mu \mathrm{m}$. Fig. 5. Haplosporidian plasmodia (arrows) situated adjacent to the nerves (N) in the epipodium in a lightly infected juvenile paua. Scale bar $=27.5 \mu \mathrm{m}$. Fig. 6. Large numbers of haplosporidian plasmodia in the gut epithelium (arrows) in a heavily infected juvenile paua. Scale bar $=44 \mu \mathrm{m}$. Fig. 7. A large focus of tissue destruction caused by haplosporidian plasmodia (area delimited by arrows) in what was previously a hemolymph space in the mantle of a heavily infected juvenile paua. Scale bar $=55 \mu \mathrm{m}$ 
paua injected with hemolymph from infected paua. Mortality rates of both infected and uninfected paua maintained at $19^{\circ} \mathrm{C}$ were higher than at $14^{\circ} \mathrm{C}$ (Table 1 , Fig. 14). Epizootics which resulted in $100 \%$ mortality of all paua occurred in Aquaria 2, 1 and 4 (control) at $19^{\circ} \mathrm{C}$ on Days 9, 17 and 27, respectively, 2, 10 and $20 \mathrm{~d}$ after introduction of uninfected paua to these respective aquaria (Fig. 14). Examination by histology found no evidence of haplosporidian infection in any of the uninfected paua sampled from Aquaria 1, 2 and 4. Histopathology indicated that mortalities of both infected and uninfected paua in these aquaria were associated with bacterial infection and heavy infestations by epicommensal ciliates on the mantle. In contrast, paua maintained in Aquarium 3 together with potential intermediate hosts survived over $50 \mathrm{~d}$ until significant mortalities were noted between Days 60 and 75. After the onset of mortalities in Aquarium 3 external bacterial infections and numerous ectocommensal ciliates were recorded by histology on both infected and uninfected paua. No haplosporidian plasmodia were found in the uninfected paua sampled from Aquarium 3 (Table 1).

In contrast mortalities in paua in Aquaria 5, 6, 7 and 8 at $14^{\circ} \mathrm{C}$ remained relatively low until around Day 70 , after which mortalities increased to between 31 and $60 \%$ by the termination of the experiment on Day 98 (Table 1, Fig. 14). Moderate numbers of ectocommensal ciliates and external bacterial infections were observed by histology in many infected and uninfected paua which died at $14^{\circ} \mathrm{C}$; however, no haplosporidian plasmodia were observed in any of the uninfected paua sampled from Aquaria 5, 6, 7 and 8. Overall mortality rates of infected paua were higher $(88 \%)$ than those of uninfected paua $(60.7 \%)$ (Table 1$)$.
Irregularly shaped spore-like bodies were apparent in the digestive gland epithelium of the majority of infected and uninfected paua sampled after more than 2 wk in aquaria at both temperatures. The bodies occurred in moderate to high numbers and appeared moderately to intensely basophillic when stained with H\&E (Fig. 15). The bodies were not demonstrated to be acid-fast when stained with the Ziehl-Neilsen method. When examined by TEM, the bodies appeared to be mineral concretions composed of numerous alternating electron-dense and electron lucent layers (Fig. 16).

\section{In situ hybridisation}

Examination of sections from infected paua using the ISH probe designed to detect rDNA of Bonamia ostreae showed moderately strong reactions with plasmodia of the haplosporidian parasite (Fig. 17) in both Davidson's and ethanol fixed material, but no reaction with the mineral concretions in the digestive gland of the paua examined. The ISH of lightly infected paua clearly demonstrated the presence of low numbers of plasmodia in the connective tissue adjacent to the gut (Fig. 17) and amongst glial cells around the periphery of nerves of the mantle and foot (Fig. 18).

\section{Screening of broodstock paua}

The 16 broodstock paua examined showed poor growth in captivity and most adhered weakly to flat surfaces. Pustular, pale-coloured foci were grossly visible on the foot, mantle and epipodium of $37.5 \%$ of

Table 2. Haliotis iris. Prevalence of the haplosporidian and other pathologies in 3 raceways (Raceway A, E and G) at the affected facility and 3 other spat producing facilities (Facilities A, B and C) surveyed using histology in August and September 2000

\begin{tabular}{|c|c|c|c|c|c|c|}
\hline & $\begin{array}{l}\text { Affected facility } \\
\text { Raceway A }\end{array}$ & $\begin{array}{l}\text { Affected facility } \\
\text { Raceway E }\end{array}$ & $\begin{array}{l}\text { Affected facility } \\
\text { Raceway G }\end{array}$ & Facility A & Facility B & Facility C \\
\hline $\begin{array}{l}\text { Time in raceway } \\
\text { prior to sampling (mo) }\end{array}$ & $14-15$ & $6-7$ & $14-15$ & $3-9$ & $3-9$ & $3-9$ \\
\hline $\begin{array}{l}\text { Number of paua } \\
\text { examined }\end{array}$ & 22 & 60 & 49 & 20 & 20 & 25 \\
\hline Haplosporidian (\%) & 50 & $0^{\mathrm{a}}$ & 87 & 0 & 0 & 0 \\
\hline $\begin{array}{l}\text { Rickettsia-like organism } \\
\text { in gut epithelium }(\%)\end{array}$ & 0 & 0 & 0 & 0 & 5 & 15 \\
\hline $\begin{array}{l}\text { Foci of bacterial infection } \\
\text { in foot and mantle }(\%)\end{array}$ & 10 & 0 & 0 & 20 & 20 & 15 \\
\hline $\begin{array}{l}\text { Foci of non specific } \\
\text { necrosis }(\%)\end{array}$ & 5 & 0 & 2 & 5 & 0 & 25 \\
\hline $\begin{array}{l}\text { Ectocommensal ciliates } \\
\text { on mantle and gills (\%) }\end{array}$ & 25 & 10 & 32.6 & 0 & 15 & 0 \\
\hline Gregarine oocysts in gills (\%) & 0 & 0 & 2 & 0 & 0 & 0 \\
\hline
\end{tabular}



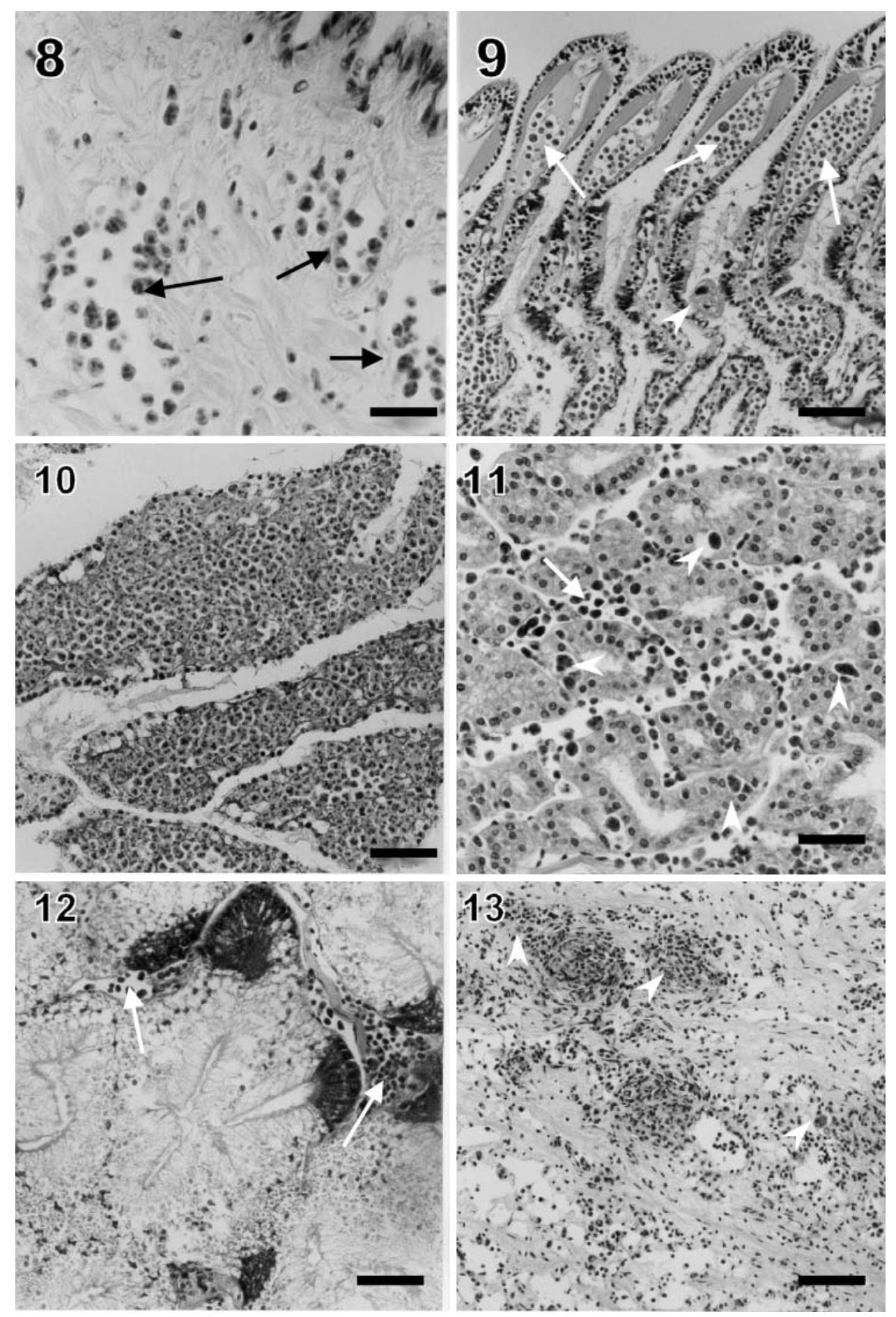

Figs. 8 to 13. Haliotis iris infected with a haplosporidian parasite. Fig. 8. Three voids containing haplosporidian plasmodia (arrows) in the epipodium of a heavily infected paua. Scale bar $=22 \mu \mathrm{m}$. Fig. 9. Large numbers of haplosporidian plasmodia (arrows) in the hemal sinuses of the gills of a heavily infected juvenile paua. Note also the ectocommensal ciliate (arrowhead). Scale bar $=55 \mu \mathrm{m}$. Fig. 10. Large numbers of haplosporidian plasmodia in the left kidney of a heavily infected juvenile paua. Scale bar $=44 \mu \mathrm{m}$. Fig. 11. Haplosporidian plasmodia in the connective tissues (arrow) and occasionally within the tubule epithelium (arrowheads) of the right kidney of a heavily infected juvenile paua. Scale bar $=22 \mu \mathrm{m}$. Fig. 12. Haplosporidian plasmodia were commonly observed in the connective tissues (arrows) surrounding the digestive gland tubules, but were rarely seen inside the digestive gland tubule epithelium. Scale bar $=55 \mu \mathrm{m}$. Fig. 13. An example of a rare multifocal hemocytosis surrounding haplosporidian plasmodia (arrowheads) in the muscle and connective tissues adjacent to the gut of a moderately infected juvenile paua. Scale bar $=73 \mu \mathrm{m}$ 
these paua, $50 \%$ had moderate to heavy conchiolin deposits inside the shell, while the remainder appeared normal. Histology demonstrated the presence of multinucleate plasmodia of a haplosporidianlike parasite in the lumen of the right kidney (Fig. 19) in 3 out of 16 broodstock paua examined (18.7\% prevalence). The plasmodia occurred in low intensity infections in only $3.7 \%$ of sections ( 3 positives in 80 sections). They occurred in plaques of adjoining plasmodia, individuals of which averaged $16 \times 10.4 \mu \mathrm{m}$ in dimension in section $(n=10)$, or about twice the average size of the plasmodia found in juvenile paua. The number of nuclei present in individual plasmodia varied with plane of section, and ranged between 3 and 16 (mean $=8.5, \mathrm{n}=15)$. Very rarely, small cysts (around 20 $\times 14 \mu \mathrm{m}$ in dimension) containing refractile, spore-like bodies averaging $3.3 \mu \mathrm{m}$ diameter (range $2.9-4 \mu \mathrm{m}$, $\mathrm{n}=16$ ), were observed amongst the plasmodia in 2 of the 3 infected broodstock (Fig. 20). The spore-like bodies were light to moderately acid-fast when stained with the Ziehl-Neilsen method (Fig. 21). These cysts may have been examples of late sporonts or early sporocysts containing the putative spore stage of the haplosporidian. Heavy epibiont infestations by ciliates and the high numbers of bacteria on external surfaces were also noted in $68 \%$ of the broodstock paua.

\section{DISCUSSION}

The Haplosporidia are a protistan group (Perkins 1989) which contains a number of internationally notifiable pathogens of molluscs including Haplosporidium nelsoni, and $H$. costale, both of which cause disease in oysters in the northern hemisphere (OIE 2000). An ultrastructural study of the novel parasite of paua which was conducted in conjunction with the present study (Hine et al. 2002) showed the parasite was a haplosporidian which possessed haplosporosomes and intracytoplasmic bacteria related to the Rickettsiales, the latter being hitherto unrecorded in haplosporidians (Hine et al. 2002). Because of this, we consider the novel parasite of paua to represent a haplosporidian of a new genus. Its identity as a haplosporidian was confirmed by sequencing of the 18S rDNA gene, which suggested that it is most closely related to the genus Urosporidium (see Reece \& Stokes in press). The cross reaction of the ISH probe designed by Cochennec et al. (2000) for Bonamia sp. with the paua haplosporidian further confirms that the affinities of the parasite lie within the Haplosporidia.

The presence of heavy infections of the novel haplosporidian was associated with a mortality rate over 10 times above that normally recorded in paua at the

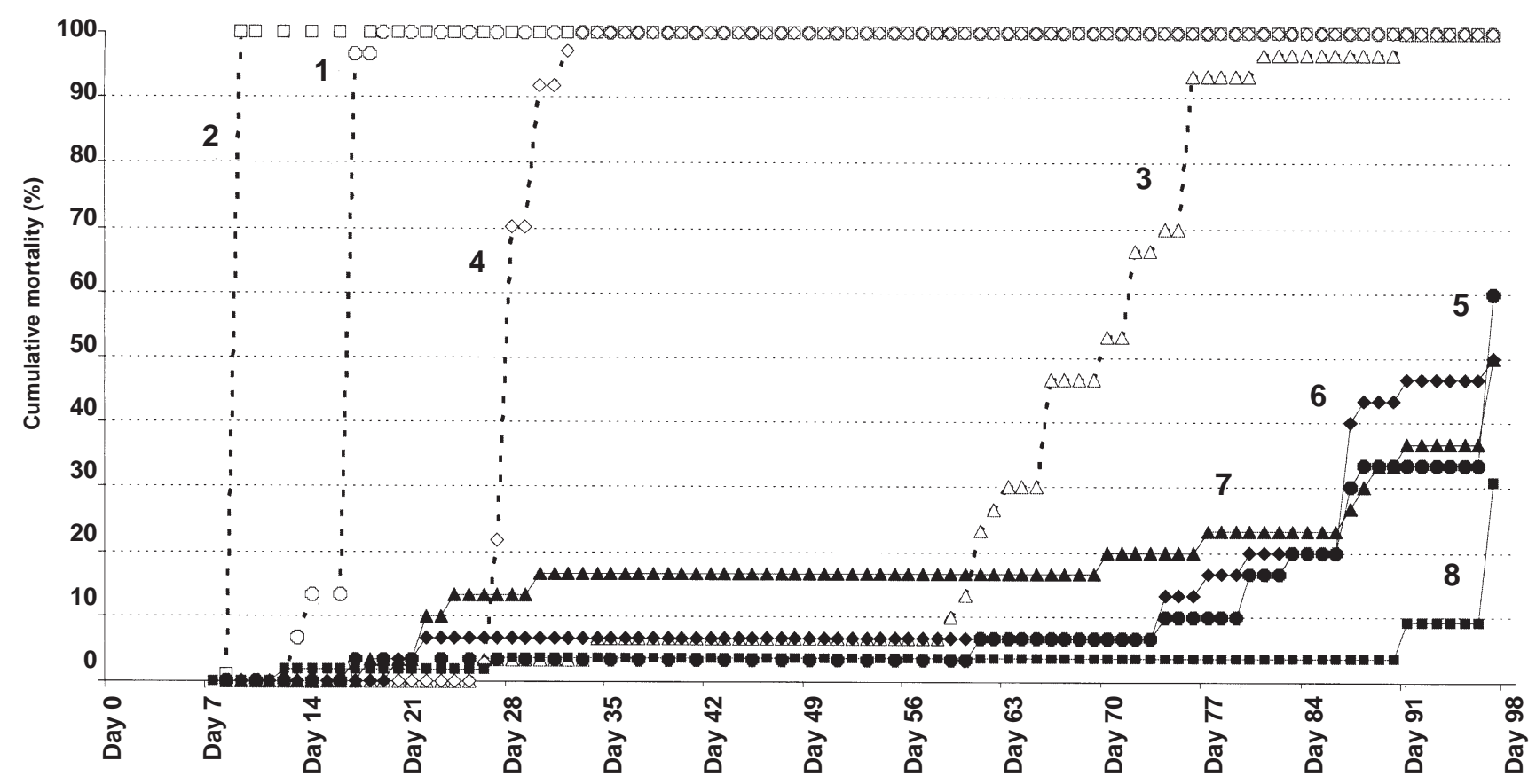

Fig. 14. Haliotis iris. Mortalities of apparently healthy paua cohabiting with haplosporidian-infected paua at $19 \pm 1^{\circ} \mathrm{C}(\mathrm{dashed}$ lines) or at $14 \pm 2{ }^{\circ} \mathrm{C}$ (solid lines). At $19^{\circ} \mathrm{C}$ : (---O---) Aquarium 1 (cohabitation only); (---口---) Aquarium 2 (cohabitation and hemolymph injection); --- $\triangle---)$ Aquarium 3 (cohabitation, hemolymph injection with potential intermediate hosts); (--- - ---) Aquarium 4 (control, uninfected paua only). At $14^{\circ} \mathrm{C}$ : (——) Aquarium 5 (cohabitation only); $(-\longrightarrow$ - Aquarium 6 (cohabitation and hemolymph injection); (- - -) Aquarium 7 (cohabitation, hemolymph injection with potential intermediate hosts); (一-) Aquarium 8 (control, uninfected paua only) 

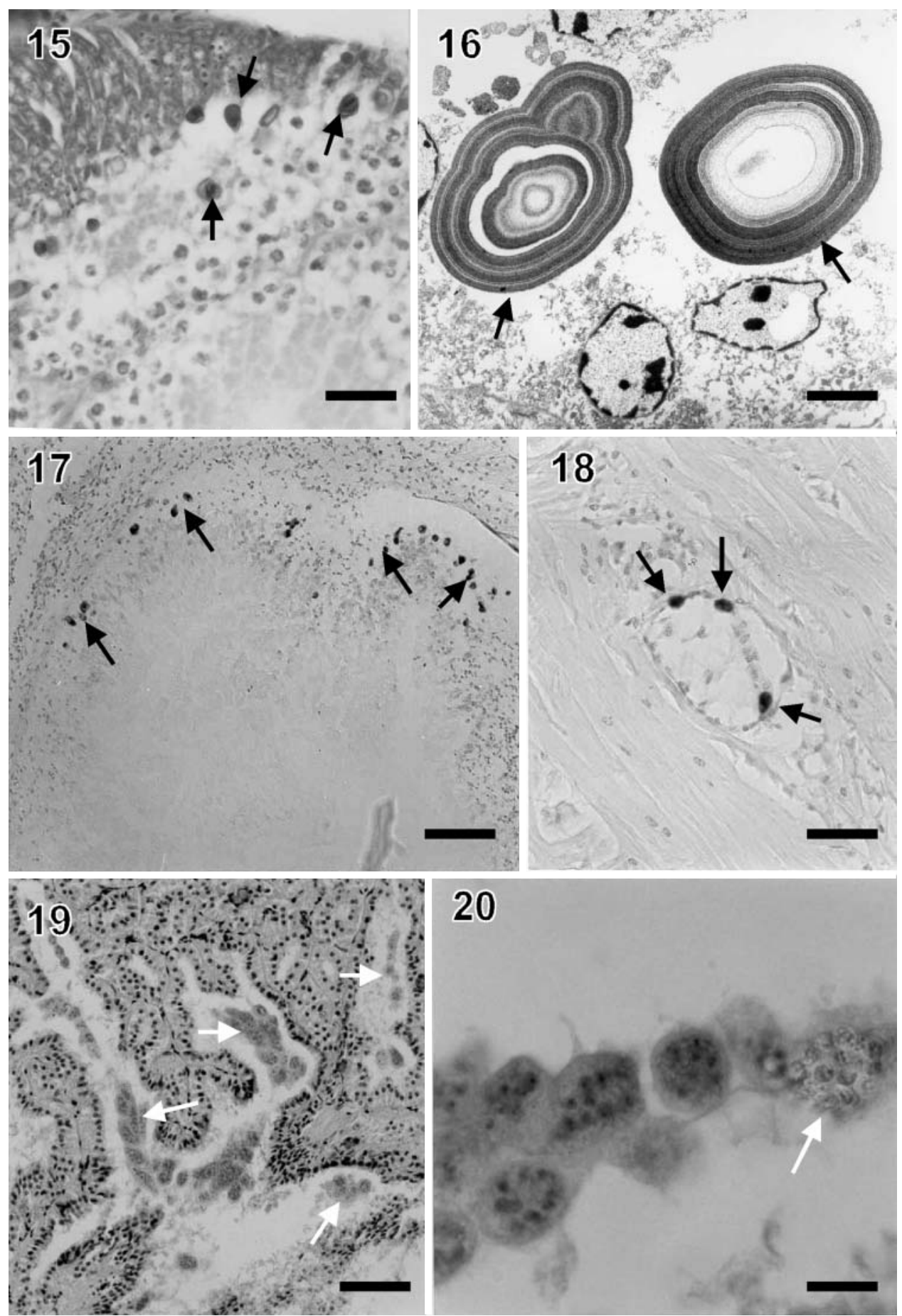

Figs. 15 to 20. Haliotis iris infected with a haplosporidian parasite. Fig. 15. Irregular shaped, intensely basophilic spore-like mineral concretions (arrows) in the epithelium of the digestive gland of a juvenile paua. Scale bar $=18.5 \mu \mathrm{m}$. Fig. 16. TEM of 2 spore-like mineral concretions (arrows) showing their composition of numerous alternating concentric electron-dense and electron-lucent layers. Scale bar $=2.3 \mu \mathrm{m}$. Fig. 17. In situ hybridisation (ISH) using a rDNA probe designed for Bonamia ostreae, showing positive reactions with low numbers of haplosporidian plasmodia (arrows) in the connective tissue surrounding the gut. Scale bar $=73.5 \mu \mathrm{m}$. Fig. 18 . Positive ISH reactions with 3 haplosporidian plasmodia (arrows) in the glial cells surrounding nerves in the epipodium of a lightly infected juvenile paua, using a probe designed for $B$. ostreae. Scale bar $=36.5 \mu \mathrm{m}$. Fig. 19. Plaques of numerous haplosporidian plasmodia (arrows) in the lumen of the right kidney of an adult paua obtained from the wild. Scale bar $=55 \mu \mathrm{m}$. Fig. 20 . Higher power view of haplosporidian plasmodia within the lumen of the right kidney of an adult paua showing a sporocyst-like cyst (arrow) containing refractile spore-like bodies considered to be examples of the putative spore stage of the parasite. Scale bar $=11 \mu \mathrm{m}$ 
affected facility. While the freshwater and chlorine treatments almost certainly exacerbated mortality in the affected paua in Raceways A and G during April 2000 (up to $24 \%$ mortality $w^{-1}$ ), apparently healthy stock in Raceway E were exposed to the same treatments as the parasitized stock. The mortality of these apparently healthy paua increased to $3-6 \% \mathrm{wk}^{-1}$ in the $2 \mathrm{wk}$ following treatment, then returned to background levels. This suggests that the 4 -fold increase in mortalities recorded in the affected stock during the chemical treatments was because the affected paua were compromised by the haplosporidian and hence were more susceptible to treatments.

The stock in Raceway E was placed in that raceway in February 2000. Sampling of 60 paua from this raceway in August/September 2000 found no evidence of infection by the haplosporidian (prevalence $<5 \%$ ); however, a sample of 5 abalone taken from Raceway $\mathrm{E}$ in April 2001 (3 mo after heavy mortalities began in that raceway) were all found to be heavily infected with the haplosporidian. Abnormal stock losses in Raceway E began in late January and early February 2001 as water temperatures peaked at $21^{\circ} \mathrm{C}$, and unlike the earlier mortalities in Raceway A, were not associated with chlorine and freshwater treatments. This indicates that the combination of infection by the haplosporidian and peak summer water temperatures is sufficient to cause mortality in infected juvenile paua. Total stock losses in Raceway E by mid-April 2001 were over $90 \%$. Mortality rates of 82.5 and $90 \%$ in both affected raceways over a period of 3 to 4 mo during summer and early autumn suggest the level of pathogenicity associated with infection of cultured paua with the haplosporidian is similar to that of other closely related, internationally notifiable mollusc pathogens (Sunila et al. 2000).

In adult paua, the presence of the haplosporidian was associated with poor growth and condition, though these signs were more likely due to maintenance under adverse conditions of poor water quality or husbandry, rather than infection with the haplosporidian. This is assumed because the haplosporidian occurred only in low numbers and at low prevalences in the right kidney, a condition perhaps representative of natural infections of adult paua in the wild. These data suggest that adult paua may be better able to combat haplosporidian infections, and thus could act as asymptomatic reservoirs of infection for cultured paua. The larger size of the plasmodia in adult paua may have been due either to the low intensity of infection (plasmodia in lightly infected juvenile paua were larger than those in heavily infected juveniles), or could have represented enlargement of plasmodia just prior to sporulation, as reported for other haplosporidians such as Haplosporidium nelsoni (see Haskin \& Andrews 1988). The distinctive halos which surrounded plasmodia within tissues and epithelium in histological sections may be evidence of production of extracellular products, possibly associated with the presence of intracytoplasmic bacteria (Hine et al. 2002). Another possibility is that the halos were due to differential shrinkage during fixation, as the plasmodia which were observed in hemolymph smears of juvenile paua were much larger (up to $25 \mu \mathrm{m}$ ) compared to those observed in tissue sections (up to $16 \mu \mathrm{m}$ ). Couch et al. (1966) reported approximately 10\% shrinkage in fixed $H$. nelsoni spores when compared to fresh material.

The haplosporidian could not be detected (prevalence $<5 \%$ ) in paua in Raceway E 6 mo after they were introduced into the raceway, but occurred at $100 \%$ prevalence and at high intensity after $12 \mathrm{mo}$. This suggests that either a narrow window of infection occurs in spring time between September and January, that the disease has a prolonged prepatent period of 3 mo or more, or that disease is only expressed at water temperatures above $20^{\circ} \mathrm{C}$, which approach, but do not exceed, the upper temperature tolerance limits of Haliotis iris (see Wells et al. 1998). Failure to transmit detectable disease horizontally

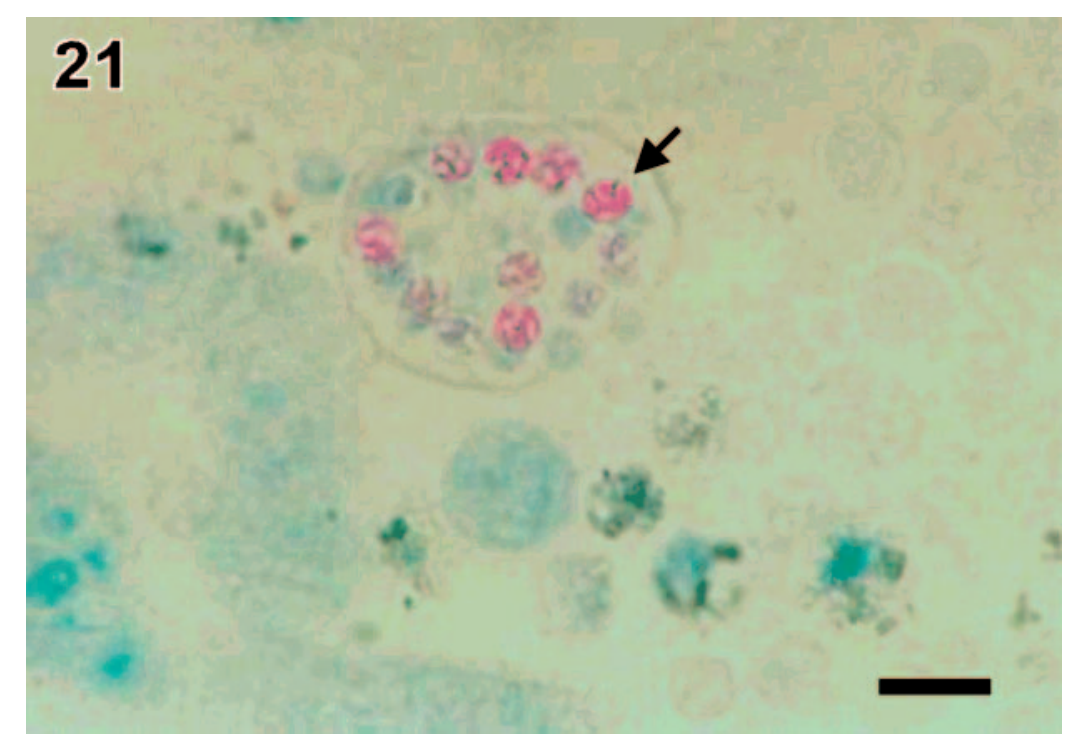

Fig. 21. Haliotis iris infected with a haplosporidian parasite. A sporocyst-like cyst in the lumen of the right kidney of an adult paua containing spore-like bodies stained acid-fast with the Zeihl-Neilsen method (arrow). Scale bar $=7 \mu \mathrm{m}$ 
from infected to apparently healthy paua via inoculation after $3 \mathrm{mo}$ at 14 and $19^{\circ} \mathrm{C}$, suggests a prepatent period of greater than 3 mo. However, it is unknown whether the disease can progress at temperatures below $20^{\circ} \mathrm{C}$ or whether inoculation of hemolymph containing plasmodia can successfully transfer disease. The fact that co-habitation for $3 \mathrm{mo}$ did not transfer infection could also mean that infective stages were not present in juvenile paua (in which spores were never observed) and/or an intermediate host is required for transmission.

Little is known about details of the lifecycle and transmission of haplosporidians (Perkins 1989), including parasites of the genus Urosporidium, to which the paua haplosporidian is most closely related. For example, the lifecycle of oyster pathogen Haplosporidium nelsoni (MSX) has never been elucidated and transmission of the parasite has never been achieved experimentally (Powell et al. 1999). This is despite numerous attempts to transmit MSX disease through implanting of infected tissue into uninfected oysters (Canzonier 1968, 1974), or feeding or injecting oysters with spores (Andrews 1979), the putative infective stage (Farley 1967). This has led to the hypothesis that an alternate host is required to complete the lifecycle of MSX disease (Powell et al. 1999), and perhaps other haplosporidians as well (Perkins 1989). However, to date no direct confirmation of this hypothesis exists (Powell et al. 1999).

Recent evidence suggests that the infective stage of Haplosporidium nelsoni is water-borne and capable of passing through a $1000 \mu \mathrm{m}$ filter (Sunila et al. 2000), and a $150 \mu \mathrm{m}$ filter (Ford et al. 2001), but not a $1 \mu \mathrm{m}$ filter followed by UV irradiation treatment (Ford et al. 2001). Sunila et al. (2000) found that infective stages from the water column overlaying a bed of MSXinfected eastern oysters could infect hatchery-raised, MSX-free juvenile Crassostrea virginica, causing 80\% mortality after $16 \mathrm{wk}$ exposure to an infected water source ranging between 15 and $26^{\circ} \mathrm{C}$. Controlled experiments using UV irradiation and $1 \mu \mathrm{m}$ filtration to exclude infective stages from the water supply at the affected facility would be desirable to investigate if infection originated from wild paua adjacent to the facility and was introduced via an untreated water supply. Furthermore, additional surveys of spat produced by commercial suppliers should be carried out to examine their role as potential sources of infection. Surveys of wild stocks of juvenile and adult paua would also be desirable to examine the natural distribution of the haplosporidian in the wild, to hopefully avoid inadvertent transfer of the disease, as has probably occurred in the past for other closely related mollusc pathogens (see Friedman 1996, Burreson et al. 2000).
Acknowledgements. The authors thank P. Redfearn and B. Hickman for providing information about the original disease outbreak, members of the paua aquaculture industry for their co-operation, hospitality and assistance during field work, and Drs. Geoff Read and Dennis Gordon for identifying shell fouling organisms. Three anonymous referees provided helpful suggestions on earlier drafts of the manuscript.

\section{LITERATURE CITED}

Andrews JD (1979) Oyster diseases in Chesapeake Bay. Mar Fish Rev 41:45-53

Annala JH, Sullivan KJ, O'Brien CJ (2000) Report from the Fishery Assessment Plenary, May 2000: stock assessments and yield estimates. NZ Ministry of Fisheries report held in NIWA library, Wellington

Burreson EM, Stokes NA, Friedman CS (2000) Increased virulence in an introduced pathogen: Haplosporidian nelsoni (MSX) in the Eastern oyster Crassostrea virginica. J Aquat Anim Health 12:1-8

Canzonier WJ (1968) Present status of attempts to transmit Minchinia nelsoni under controlled conditions. Proc Natl Shellfish Assoc 58:1

Canzonier WJ (1974) Tissue grafts in the American oyster Crassostrea virginica. Proc Natl Shellfish Assoc 64:92-101

Clark CB, Creese RG (1998) On-growing cultured abalone (Haliotis iris) in northern New Zealand. J Shellfish Res 17:607-613

Cochennec N, LeRoux F, Berthe F, Gerard A (2000) Detection of Bonamia ostreae based on small sub unit ribosomal probe. J Invertebr Pathol 76:26-32

Couch JA, Farley CA, Rosenfield A (1966) Sporulation of Minchinia nelsoni (Haplosporida, Haplosporidiidae) in Crassostrea virginica (Gmelin). Science 153:1529-1531

Farley CA (1967) A proposed life cycle of Minchinia nelsoni (Haplosporidia, Haplosporidiidae) in the American oyster Crassostrea virginica. J Protozool 14:616-625

Ford SE, Xu Z, Debrosse G (2001) Use of particle filtration and UV irradiation to prevent infection by Haplosporidium nelsoni (MSX) and Perkinsus marinus (Dermo) in hatchery reared larval and juvenile oysters. Aquaculture 194:37-49

Friedman CS (1996) Haplosporidian infections in the Pacific oyster Crassostrea gigas (Thunberg), in California and Japan. J Shellfish Res 15:597-600

Friedman CS, Andree KB, Beauchamp KA, Moore JD, Robbins TT, Shields JD (2000) Candidatus Xenohaliotis californiensis gen. nov. sp. nov., a pathogen of abalone, Haliotis spp., along the west coast of North America. Int J Syst Evol Bacteriol 50:847-855

Gardner GR, Harshbarger JC, Lake JL, Sawyer TK, Price KL, Stephenson MD, Haaker PL, Togstad HA (1995) Association of prokaryotes with symptomatic appearance of withering syndrome in black abalone Haliotis cracherodii. J Invertebr Pathol 66:111-120

Grindley RM, Keogh JA, Friedman CS (1998) Shell lesions in New Zealand Haliotis sp. (Mollusca gastropoda). J Shellfish Res 17:805-811

Haskin HH, Andrews JD (1988) Uncertainties and speculations about the life cycle of the eastern oyster pathogen Haplosporidium nelsoni (MSX). Am Fish Soc Spec Publ 18:5-22

Hine PM, Wakefield S, Diggles BK, Webb V (2002) The ultrastructure of a haplosporidian containing Rickettsiae, associated with mortalities among cultured paua Haliotis iris. Dis Aquat Org 49:207-219 
Luna LG (ed) (1968) Manual of histologic staining methods of the Armed Forces Institute of Pathology, 3rd edn, McGraw-Hill, New York, p 38-39

Nakatsugawa T, Nagai T, Hiya K, Nishizawa T, Muroga $K$ (1999) A virus isolated from juvenile black abalone Nordotis discus discus affected with amyotrophia. Dis Aquat Org 36:159-161

Office International des Epizooties (OIE) (2000) International Aquatic Animal Health Code, fish, molluscs and crustaceans, 3rd edn. OIE, Paris

Perkins FO (1989) Phylum Haplosporidia. In: Margulis L, Corliss JO, Melkonian M, Chapman DJ, McKann HI (eds) Handbook of Protoctista. Jones and Bartlett, Boston, p 19-29

Powell EN, Klinck JM, Ford SE, Hofmann EE, Jordan SJ (1999) Modeling the MSX parasite in eastern oyster (Crassostrea virginica) populations. III. Regional application and the problem of transmission. J Shellfish Res 18:517-537

Editorial responsibility: Albert Sparks,

Seattle, Washington, USA
Preece MA, Mladenov PV (1999) Growth and mortality of the New Zealand abalone Haliotis iris Martyn 1784 cultured in offshore structures and fed artificial diets. Aquacult Res 30:865-877

Reece KS, Stokes NA (in press) Molecular analysis of a haplosporidian parasite from cultured New Zealand abalone Haliotis iris. Dis Aqat Org

Sunila I, Karolus J, Lang EP, Mroczka ME, Volk J (2000) Transmission of the haplosporidian parasite MSX Haplosporidium nelsoni to the eastern oyster Crassostrea virginica in an upweller system. Dis Aquat Org 42: 153-155

Wells RMG, Baldwin J, Speed SR, Weber RE (1998) Haemocyanin function in the New Zealand abalones Haliotis iris and $H$. australis: relationships between oxygen binding properties, muscle metabolism and habitat. Mar Fresh Res 49:143-149

Submitted: July 18, 2001; Accepted: January 23, 2002

Proofs received from author(s): July 4, 2002 